\title{
PERFORMANCE OF V-4Cr-4Ti MATERIAL EXPOSED TO THE DIII-D TOKAMAK ENVIRONMENT *
}

H. Tsai, D. L. Smith, and H. M. Chung

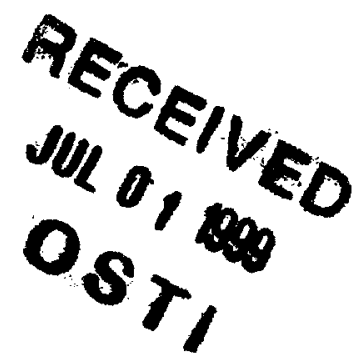
Argonne National Laboratory

Argonne, IL 60439

W. R. Johnson and J. P. Smith

General Atomics

San Diego, CA 92138

W. R. Wampler

Sandia National Laboratories

Albuquerque, NM 87185

October 1997

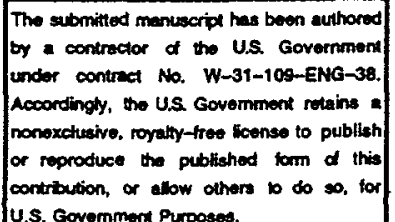

U.S. Government Purposed.

For presentation at 8th International Conference on Fusion Reactor Materials, Sendai, JAPAN, October 26-31, 1997

*Work supported by U.S. Department of Energy, Office of Fusion Energy Research, under Contract W-31-109-Eng-38. 


\section{DISCLAIMER}

This report was prepared as an account of work sponsored by an agency of the United States Government. Neither the United States Government nor any agency thereof, nor any of their employees, make any warranty, express or implied, or assumes any legal liability or responsibility for the accuracy, completeness, or usefulness of any information, apparatus, product, or process disclosed, or represents that its use would not infringe privately owned rights. Reference herein to any specific commercial product, process, or service by trade name, trademark, manufacturer, or otherwise does not necessarily constitute or imply its endorsement, recommendation, or favoring by the United States Government or any agency thereof. The views and opinions of authors expressed herein do not necessarily state or reflect those of the United States Government or any agency thereof. 


\section{DISCLAIMER}

Portions of this document may be illegible in electronic image products. Images are produced from the best available original document. 


\title{
Performance of V-4Cr-4Ti Material \\ Exposed to the DIII-D Tokamak Environment
}

\author{
H. Tsai,* W. R. Johnson, ${ }^{* *}$ D. L. Smith,* J. P. Smith, ${ }^{* *}$ H. M. Chung,* \\ and W. R. Wampler*** \\ *Argonne National Laboratory \\ Argonne, IL 60439 USA \\ **General Atomics \\ San Diego, CA 92138 USA \\ ***Sandia National Laboratories \\ Albuquerque, NM 87185 USA
}

\begin{abstract}
A series of tests is being conducted in the DIII-D tokamak to determine the effects of environmental exposure on a $\mathrm{V}-4 \mathrm{Cr}-4 \mathrm{Ti}$ vanadium alloy. These tests are part of the effort to build and install a water-cooled vanadium alloy structure in the DIII-D radiative divertor upgrade. Data from the test series indicate that the performance of the $\mathrm{V}-4 \mathrm{Cr}-4 \mathrm{Ti}$ alloy would not be significantly affected by environmental exposure. Interstitial absorption by the material appears to be limited to the surface, and neither the tensile nor the impact properties of the material appear to be affected by the exposure.
\end{abstract}

Keywords D01, D06, E04, S09, V01

\section{Introduction}

One of the promising features of fusion as an energy source is its potentially low impact on the environment.[1] To reliaze this potential, however, low-activation materials must be used in the construction of fusion systems. In this respect, V-base alloys[2,3] are attractive, because they not only exhibit inherently low neutron-induced activation but they also exhibit the good thermal and mechanical properties that are required for high system performance. 
As one important step to demonstrate the viability of $\mathrm{V}$-alloys as a structural material for tokamaks, full-size components made with a newly procured $\mathrm{V}-4 \mathrm{Cr}-4 \mathrm{Ti}$ alloy (Heat 832864)[4] will be installed in the radiative divertor of the DII-D tokamak. $[5,6]$ The objective of the project is to demonstrate both the feasibility of constructing large components with V-base alloys and the satisfactory performance of these components in service. Because the components will be exposed to a wide range of environmental conditions that may affect the properties of the material, tests with coupon-size specimens are being conducted in DII-D to obtain early performance data. The results from these tests, on specimens made from a comparable $\mathrm{V}-4 \mathrm{Cr}-$ 4Ti alloy (Heat 832665)[7], are the subject of this paper.

\section{Objective}

In service, the $\mathrm{V}-4 \mathrm{Cr}-4 \mathrm{Ti}$ divertor components in the DIII-D will be exposed to a range of temperature and impurity conditions typical of today's tokamak plasma physics experiments. These conditions include alternating vacuum/low-pressure $H$ plasma operation, thermal cycles and periodic bakeout, glow discharge cleaning with $\mathrm{He}$, periodic $\mathrm{B}$ coating, and occasional reexposure to air during vents for maintenance. The objective of the lead tests is to determine the effects of these environmental exposures on the performance of the $\mathrm{V}$ alloy material. It is particularly important that we determine whether interstitial impurities $(\mathrm{O}, \mathrm{H}, \mathrm{C}$, and $\mathrm{N})$ are absorbed in significant quantities to cause material embrittlement.

\section{Experiment and Specimen Description}

The test series consisted of four tests. Tests $\mathrm{D} 1$ and D2 were designed to study the effects of bakeouts after an air and $\mathrm{N}_{2}$ vent, respectively. Because of the elevated temperatures and high 
concentrations of gaseous impurities during the bakeouts, the potential of material degradation would probably be the greatest in these periods. Tests W1 and W2 were designed to study the long-term effects of cumulative events (including bakeouts) during single- and multiple-cycle operations.

Tests D1 and D2 utilized the Divertor Materials Evaluation System (DiMES)[8], a device that is located below the vessel floor and when extended, allows specimens mounted on it to be inserted into the plasma chamber without disturbing the system vacuum. Tests W1 and W2 utilized a fixed mount on the DIII-D chamber wall behind the divertor baffle plate; specimen installation and retrieval were performed with a manned entry during the air vent between cycles, which are typically $\approx 8-10$ months long. By design, none of the specimens from the lead tests directly interacted with the plasma.

\section{The D1 Test}

The specimen for the D1 test was a polished disk, $33.0 \mathrm{~mm}$ in diam. and $3.8 \mathrm{~mm}$ thick. Approximately the center one-third of the disk was exposed to the vessel atmosphere via the opening of the graphite retaining ring on the DiMES. The exposure occurred during the bakeouts on April 1, 9, 15 and 16, 1995, following an air vent in March. The exposure conditions, as determined by the DIII-D's infrared camera and the residual gas analyzer (RGA), are summarized in Table 1. In each of the four bakeouts, the duration at temperature was $\approx 5-10 \mathrm{~h}$. During the experiment, the sample surface was recessed $\approx 3.8 \mathrm{~mm}$ below the DIII-D graphite tile floor. 
Table 1. Summary of exposure conditions during the $\mathrm{D} 1$ test $^{\mathrm{a}}$

\begin{tabular}{|c|c|c|c|c|c|c|}
\hline \multirow{2}{*}{$\begin{array}{l}\text { Bakeout } \\
\text { Date }\end{array}$} & \multirow{2}{*}{$\begin{array}{c}\text { Temp. } \\
\left({ }^{\circ} \mathrm{C}\right)\end{array}$} & \multirow{2}{*}{$\begin{array}{l}\text { Pressure } \\
\text { (torr) }\end{array}$} & \multicolumn{4}{|c|}{ Impurity Partial Pressure $\left(\times 10^{-9} \mathrm{~atm}\right)$} \\
\hline & & & $\mathrm{H}_{2} \mathrm{O}$ & $\mathrm{N}_{2}$ & $\mathrm{CO}$ & $\mathrm{O}_{2}$ \\
\hline $\begin{array}{c}4 / 1 / 95 \\
4 / 9 / 95 \\
4 / 15 / 95 \\
4 / 16 / 95 \\
\end{array}$ & $\begin{array}{l}250 \\
150 \\
325 \\
325 \\
\end{array}$ & $\begin{array}{l}4.6 \times 10^{-4} \\
1.1 \times 10^{-3} \\
2.6 \times 10^{-4} \\
6.2 \times 10^{-5}\end{array}$ & $\begin{array}{r}490 \\
1400 \\
240 \\
67 \\
\end{array}$ & $\begin{array}{l}0.016 \\
0.018 \\
0.013 \\
0.003 \\
\end{array}$ & $\begin{array}{l}80 \\
30 \\
64 \\
11\end{array}$ & $\begin{array}{l}3.1 \\
3.5 \\
2.6 \\
0.6\end{array}$ \\
\hline
\end{tabular}

${ }^{2}$ All values are peak readings.

\section{The D2 Test}

In the D2 test, five miniature Charpy specimens were exposed with the DiMES during a single bakeout on June 6,1995 , that following a clean (i.e., $\mathrm{N}_{2}$ ) vent. The vent, for diagnostic repairs, lasted 35 days. Exposure conditions, as determined from temperatures measured in the inner and outer vessel wall and from RGA measurements, are summarized in Table 2. The Charpy specimens were $1 / 3$ size $(3.3 \times 3.3 \times 25.4 \mathrm{~mm})$ and contained a $0.6-\mathrm{mm}$-deep, $30^{\circ}$ blunt notch with a root radius of $0.08 \mathrm{~mm}$. The direction of the crack plane was perpendicular to the rolling direction and through the thickness of the plate from which the specimens were prepared. After machining and before exposure, the specimens were annealed in vacuum at $1000^{\circ} \mathrm{C}$ for $1.0 \mathrm{~h}$ in a pure Ti foil wrap, which acted as an impurity getter.

Table 2. Summary of exposure conditions during the $\mathrm{D} 2$ test $^{\mathrm{a}}$

\begin{tabular}{|c|c|c|c|c|c|c|}
\hline \multirow{2}{*}{$\begin{array}{c}\text { Bakeout } \\
\text { Date }\end{array}$} & \multirow{2}{*}{$\begin{array}{c}\text { Temp. } \\
\left({ }^{\circ} \mathrm{C}\right)\end{array}$} & \multirow{2}{*}{$\begin{array}{l}\text { Pressure } \\
\text { (torr) }\end{array}$} & \multicolumn{4}{|c|}{ Impurity Partial Pressure $\left(\times 10^{-9} \mathrm{~atm}\right)$} \\
\hline & & & $\mathrm{H}_{2} \mathrm{O}$ & $\mathrm{N}_{2}$ & $\mathrm{CO}$ & $\mathrm{O}_{2}$ \\
\hline $7 / 13 / 95$ & 250 & $5.5 \times 10^{-5}$ & 31 & 0.33 & 2.4 & 0.08 \\
\hline
\end{tabular}




\section{The W1 Test}

In the W1 test, five Charpy and five tensile specimens were exposed for an entire DII-D operation cycle, from February through December 1995. The configuration of the Charpy specimens was the same as in the D2 test. The tensile specimens were $25.4 \mathrm{~mm}$ long, with a gauge section that was $7.62 \mathrm{~mm}$ long, $1.52 \mathrm{~mm}$ wide, and $0.76 \mathrm{~mm}$ thick. The long direction of the gauge section was parallel to the final rolling direction of the plate from which the tensile specimens were machined. All specimens were annealed in vacuum at $1000^{\circ} \mathrm{C}$ for $1.0 \mathrm{~h}$ prior to the test. For the exposure, the specimens were held in a frame mounted on the vessel wall behind the divertor baffle plate. The temperature of the specimens was measured with four thermocouples attached to the ends of the specimens.

During the test, the specimens were exposed for 265 days in a complete range of DIII-D operating conditions. In their positions behind the divertor baffle plate, the specimens would be most affected only by those DII-D operations for which the specimens would have been heated to elevated temperatures and at which the greatest interactions with gaseous impurities in the DIII-D environment might be expected. These operations included the elevated-temperature bakeouts and boronizations.[9] Based on the specimen thermocouple data, the temperatures of the specimens reached values of $\approx 150-300^{\circ} \mathrm{C}$ during bakeouts and $\approx 250-280^{\circ} \mathrm{C}$ during boronizations. Analysis of the RGA monitoring data obtained during the exposure period indicated that, depending on the type of vent, the specimens were exposed to impurity levels generally within the range of the impurities indicated in Tables 1 and 2. A summary of the various vents and bakeouts experienced by the specimens in the W1 test is presented in Table 3 . 
Table 3. DIII-D environment history (number of events) for the W1 test performed February - December, 1995

\begin{tabular}{cccccc}
\hline & $\begin{array}{c}150^{\circ} \mathrm{C} \\
\text { Air }\end{array}$ & $\begin{array}{c}\text { Nakeouts } \\
(4-6 \mathrm{~h} \\
\text { Vents }\end{array}$ & $\begin{array}{c}200-250^{\circ} \mathrm{C} \\
\text { Bakeouts } \\
(2-7 \mathrm{~h} \\
\text { duration })\end{array}$ & $\begin{array}{c}280-350^{\circ} \mathrm{C} \\
\text { Bakeouts } \\
(5-20 \mathrm{~h} \\
\text { duration })\end{array}$ & $\begin{array}{c}280^{\circ} \mathrm{C} \\
\text { Boronizations } \\
(5.5 \text { h duration })\end{array}$ \\
\hline 5 & 5 & 2 & 3 & 20 & 2 \\
\hline
\end{tabular}

\section{The W2 Test}

The W2 test is still ongoing in the DIII-D at the time of writing. Similar to the W1 test, five Charpy and five tensile specimens are being exposed on a mounted frame behind the divertor baffle plate. The planned exposure is three complete DIII-D operation cycles, from January 1996 through August 1998.

\section{Test Results}

The specimens from tests D1, D2, and W1 have been evaluated and the findings indicate that, although there were measurable effects from the exposures, the overall impact of the exposures on the properties of the material was insignificant.

The effects of bakeouts after the air vent were studied during the D1 test. Examination of the disk specimen was limited to surface $\mathrm{H}$ analysis and microhardness measurements. The geometry of the specimen was not amenable to mechanical testing and none was conducted.

The exposed area of the D1 disk exhibited a slight loss of luster. Surface $\mathrm{H}$ analyses, by an elastic recoil diffraction technique[10] with a $2.6 \mathrm{MeV}^{4} \mathrm{He}$ beam, showed pronounced surface peaks of $\approx 25,000$ appm for the front (i.e., exposed) side and $\approx 65,000$ appm for the back side. The concentration profiles for both sides, however, decrease rapidly with depth within the first $\approx 0.1 \mu \mathrm{m}$. At a depth of $\approx 0.45 \mu \mathrm{m}$, the limit of beam penetration, the concentrations appear to 
have reached an asymptote of $\approx 7,000$ appm for both sides. The fact that the $\mathrm{H}$ concentration is gxeater on the back side suggests the high surface readings may be a storage or handling artifact unrelated to the actual DIII-D exposure. Microhardness tests were performed with a light load $(10 \mathrm{~g})$ to minimize the depth of indentation. Readings taken at locations of the exposed front surface, the nonexposed front surface (i.e., beneath the graphite retaining ring), and the nonexposed back surface were essentially the same $(205 \pm 15 \mathrm{KHN})$ and consistent with nonexposed control data.

The effects of the post- $\mathrm{N}_{2}$-vent bakeout on the material's impact properties were studied with the Charpy specimens of the D2 test. The energy-vs.-temperature curve from the impact testing of the specimens is shown in Fig. 1 along with nonexposed sibling data.[11] The results indicate that, although there appears to be a slight reduction of the upper shelf energy after the exposure, all of the specimens are still ductile over the test temperature range of -190 to $150^{\circ} \mathrm{C}$. The ductile-to-brittle transition temperature remains very low, $<-150^{\circ} \mathrm{C}$. The SEM fractograph of the $-130^{\circ} \mathrm{C}$ test specimen, shown in Fig. 2 , indicates the fracture mode to be ductile shear.

The composite effect of the exposure to an entire DIII-D operating cycle was studied during the W1 test. This test contained both tensile and Charpy specimens. The postexposure tensile tests were conducted at room temperature in air and at $350^{\circ} \mathrm{C}$ in high-purity Ar. The strain rate was $1.1 \times 10^{-3} / \mathrm{s}$. The results, summarized in Table 4 , indicate that, in spite of the long exposure, there was little change in the strength or ductility when compared with the nonexposed control.[11] The SEM fractograph of the room-temperature tensile specimen (Fig. 3) shows the fracture consisted of ductile dimples and microvoid coalescence. The exposed surface of this tensile specimen away from the gauge section was examined with an electron microprobe to determine the depth profile of interstitial elements $\mathrm{O}, \mathrm{C}$, and $\mathrm{N}$. The results, when compared with those of a nonexposed control, show interstitial pickup to be minor and limited to only a 
thin layer $(<0.1 \mu \mathrm{m}$ thick) of the surface. No discernible differences were detected in the interstitial content beyond that depth. The lack of substantial interstitial uptake corroborates well with the measured tensile data. The postexposure Charpy impact tests were conducted at -190 to $150^{\circ} \mathrm{C}$; the results are shown in Fig. 1. Similar to those of the D2 test, the effects of the exposure appear to be limited. The SEM fractograph of the $-150^{\circ} \mathrm{C}$ specimen confirmed the fracture to be ductile.

Table 4. Tensile properties of specimens exposed in the W1 test in DII-D

\begin{tabular}{ccccc}
\hline & \multicolumn{4}{c}{ Test Temperature } \\
\cline { 2 - 5 } Tensile Property & \multicolumn{3}{c}{$350^{\circ} \mathrm{C}$} \\
\hline & DIII-D & Control & DIII-D & Control $^{\text {b }}$ \\
YS (MPa) & 334 & 357 & 241 & 205 \\
UTS (MPa) & 449 & 428 & 377 & 359 \\
UE (\%) & 19.0 & 19.1 & 14.8 & 17.6 \\
TE (\%) & 27.0 & 29.2 & 22.0 & 25.4 \\
\hline
\end{tabular}

D YS: $0.2 \%$ offset yield stress; UTS: engineering ultimate tensile stress; UE: uniform elongation; TE: total elongation.

${ }^{\circ}$ Conducted at $400^{\circ} \mathrm{C}$.

\section{Conclusions}

Although the available data from the tests were limited to one cycle of operation, all of the data suggest that the effect of exposing $\mathrm{V}-4 \mathrm{Cr}-4 \mathrm{Ti}$ divertor components to the DII-D environment are benign. Interstitial impurity uptake is limited to only the shallow surface and does not alter the bulk material. Neither the tensile nor the impact properties of the $\mathrm{V}-4 \mathrm{Cr}-4 \mathrm{Ti}$ alloy were significantly affected by a cycle-long exposure. When the three-cycle-exposure specimens from the ongoing W2 test become available, they will be tested and analyzed and hopefully povide confirmation of these positive conclusions. 


\section{Acknowledgements}

The authors thank the DII-D staff at General Atomics for conducting the experiments, D. Walsh at Sandia National Laboratories for conducting the hydrogen analyses, and L. Nowicki and R. Lee at Argonne National Laboratory for postexposure testing and examination.

\section{References}

1. E. A. Hoffman et al., "Radioactive Waste Disposal Characteristics of Candidate Tokamak Demonstration Reactors," Fusion Technology, 31 pp. 35-62 (1997).

2. D. L. Smith et al., "Fusion Engineering and Design, 29 p. 399 (1995).

3. D. L. Smith et al., "Reference Vanadium Alloy V-4Cr-4Ti for Fusion Applications," J. of Nuclear Materials, 233-237, pp. 356-363 (1996.

4. W. R. Johnson et al., "Production and Fabrication of Vanadium Alloys for the Radiative Divertor Program of DII-D," Fusion Reactor Materials Semiannual Progress Report, DOE/ER-0313/20, Oak Ridge National Laboratory, Oak Ridge, TN, pp. 3-10 (1996).

5. “System Design Description of DIII-D," General Atomics Report GA-A19264, Feb. 1989.

6. J. P. Smith et al., "Utilization of Vanadium Alloys in the DII-D Radiative Divertor Program," J. of Nuclear Materials, 233237, pp. 421-425 (1996). 
7. H. M. Chung et al., "Fabrication of 500-kg Heat of V-4Cr-4Ti," Fusion Reactor Materials Semiannual Progress Report, DOE/ER-0313/17, Oak Ridge National Laboratory, Oak Ridge, TN, pp. 5-11 (1995).

8. C. P. C. Wang et al., "Divertor Materials Evaluation System at DIII-D," J. of Nuclear Materials, 196-198, pp-871-875 (1992).

9. G. L. Jackson et al., "Boronization in DIII-D," J. Nuclear Materials, 196-198, p. 236 (1992).

10. J. B. Barbour and B. L. Doyle, "Elastic Recoil Detection: ERD," pp. 83-138 in Handbook of Modern Ion Beam Materials Analysis, eds. J. R. Tesmer and M. Nastasi, Materials Research Society, Pittsburgh, 1995.

11. H. M. Chung et al., "Effects of Annealing on Impact Properties of Production-Scale Heat of V-4Cr-4Ti," Fusion Reactor Materials Semiannual Progress Report, DOE/ER0313/18, Oak Ridge National Laboratory, Oak Ridge, TN, pp. 273-278 (1995).

12. M. C. Billone et al., "Revision of the Tensile Database for V-Ti and V-Cr-Ti Alloys Tested at ANL," Proc. 8th Conf. on Fusion Reactor Materials (1997), to be published. 


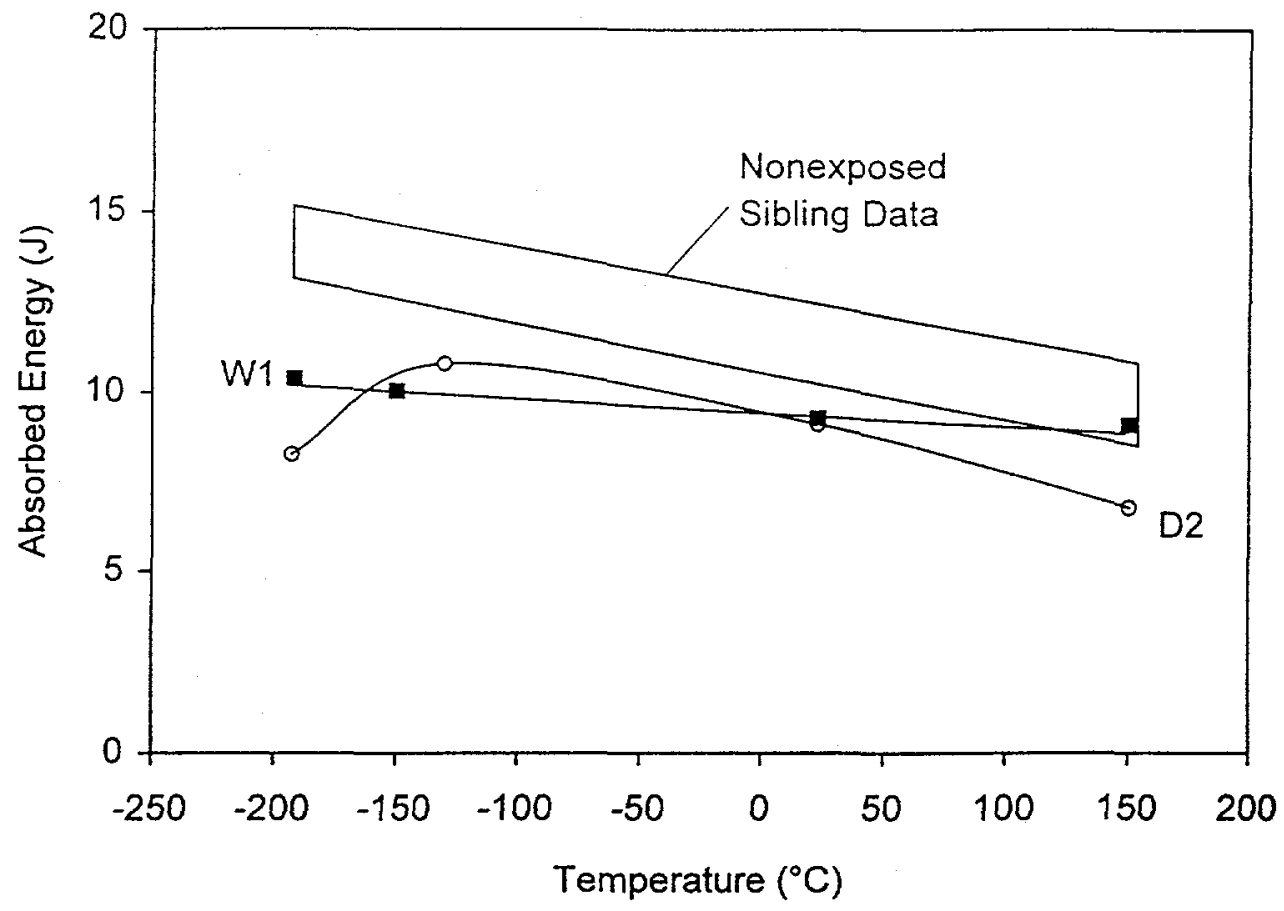

Fig. 1. Charpy impact data for the D2 and W1 tests, showing ductile behavior of exposed specimens even at $\approx-190^{\circ} \mathrm{C}$.

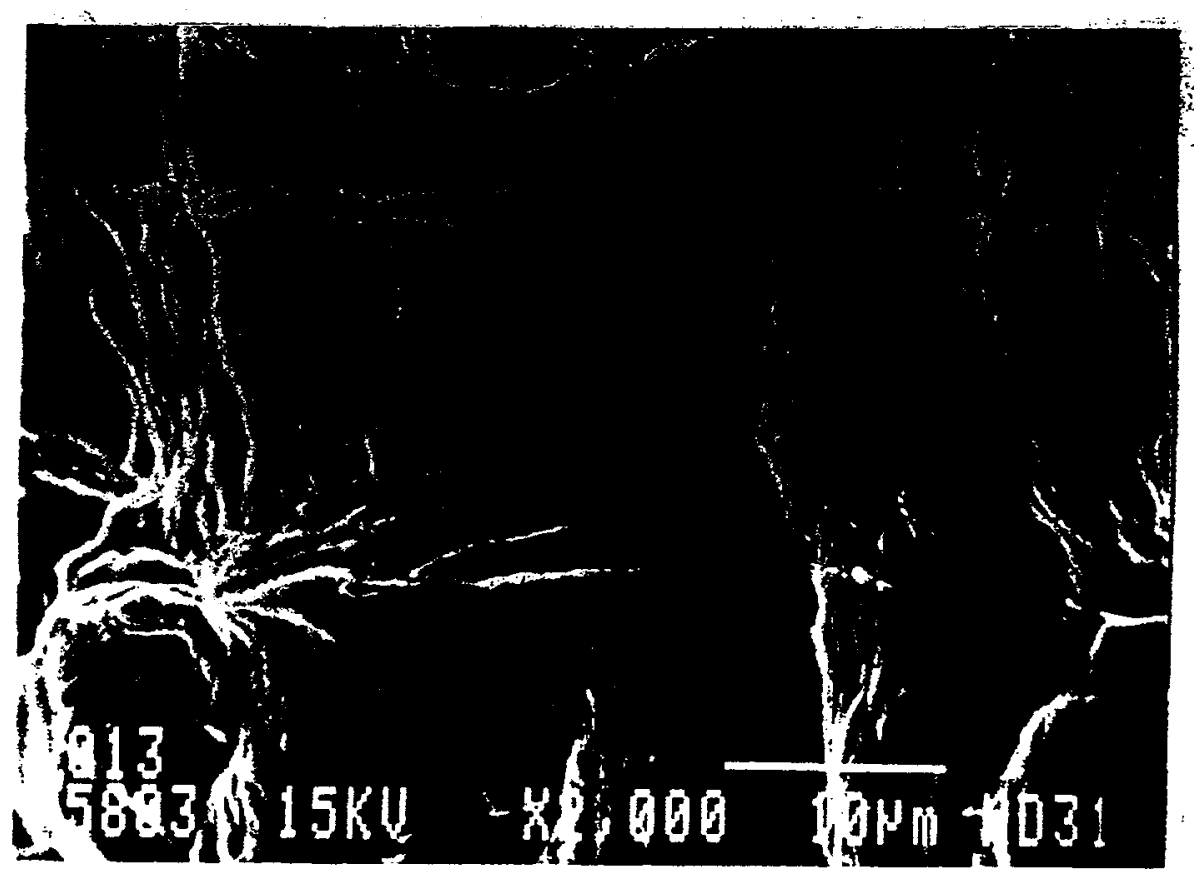

Fig. 2. SEM fractograph of $\mathrm{D} 2$ test specimen impact-tested at $-130^{\circ} \mathrm{C}$. Fracture mode was ductile. 


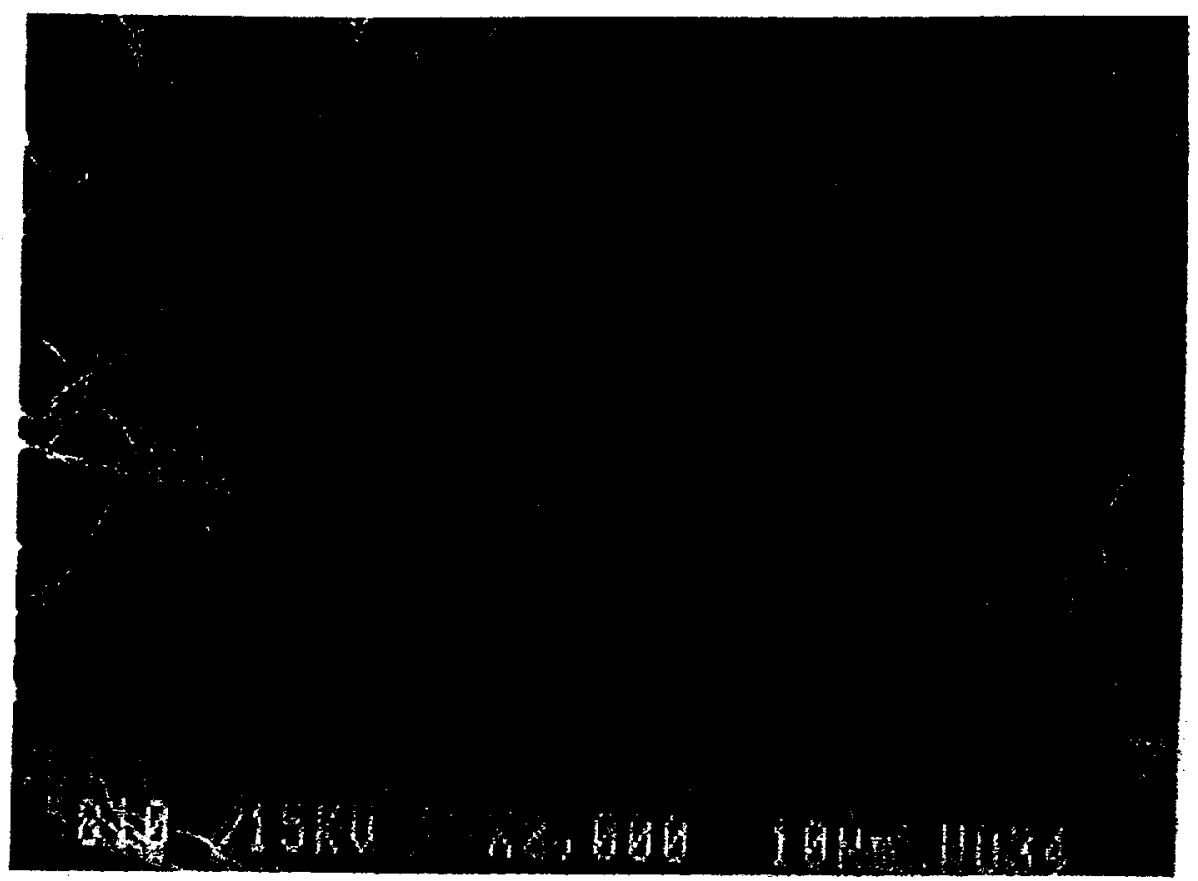

Fig. 3. SEM fractograph of tensile specimen from W1 test. Fracture mode was ductile. 